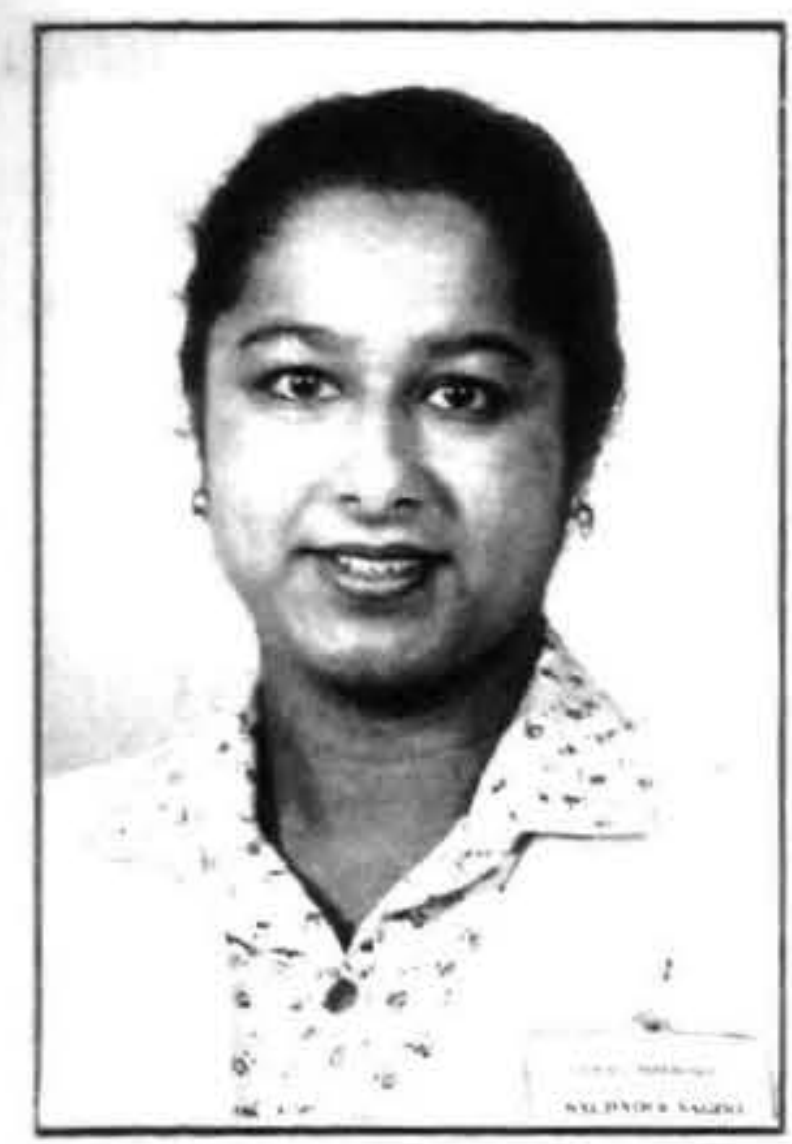

\title{
THE QUALIFICATIONS AND EXPERIENCE OF NEW ZEALAND'S KEY DECISION MAKERS
}

\author{
Baljinder Sagoo
}

Ministry of Research, Science and Technology

\begin{abstract}
In order to be more competitive, New Zealand's labour force must be more skilled and educated. Having a qualification is seen as a key to getting into the labour market, into employment and into work. Obtaining information and data on what qualifications New Zealanders have and need is relatively easy. But little is known about the distribution of individuals in relation to their qualifications. There have been many claims made that "New Zealand has too many accountants and lawyers in key positions and not enough scientists and engineers". Earlier studies have suggested there is an over-emphasis on accountancy and law as business qualifications. What is not clear is the extent to which other fields of study are represented amongst New Zealand's key decision makers. This paper is based on a comprehensive survey of the qualifications and experience of New Zealand's key decision makers, that is, individuals likely to affect significant decisions made in the private and public sectors within New Zealand. It aims to provide a clearer picture of the extent to which business versus technology related and other qualifications and experience exist amongst senior personnel.
\end{abstract}

Many changes have been made in the school, university and polytechnic environments to encourage students to stay at school longer and for people to obtain or upgrade their qualifications. In theory, having a qualification should improve an individuals personal career choice as well as raising the overall qualification level in New Zealand. It is now possible to obtain a qualification at home, after work or during work hours, on a part-time basis or a fulltime basis. Qualifications can also be obtained over different time ranges, for example, 6 months or 10 years. The options have started to become limitless. But with all these options, how do we know what the best qualification to get is?

An accountant may suggest an accounting degree to learn how to handle money. Medicine could be for individual's interested in money and status. We often see articles which indicate that, there are 'too many accountants and lawyers' and not enough scientists and engineers in New Zealand's key positions.

Too many New Zealand firms have managements populated by accountants who are good cost controllers but lack the forward-looking orientation necessary to the innovation process. This is in stark contrast with the technical backgrounds of the management of most German and Japanese firms...

New Zealand tends not to be successful in industries such as consumer goods, finance or technical products, that require skills in marketing, finance or management of new technologies. Experienced people with sophisticated marketing, financial and managerial skills, in fact, are in short supply throughout the New Zealand economy. 1

Statements such as these highlight claims made in New Zealand and overseas. It has been said that by having more scientists, engineers and technologists at the 'top', there would be a more diverse range of qualifications and experiences in the positions. With respect to science and technology it is assumed this would lead to a greater acceptance of the opportunities arising from technological change. Especially since technological understanding and literacy have been recognised as areas where New Zealand needs to upgrade in with respect to gaining competitive advantages. Further, it is New Zealand's lack of technological awareness which has been blamed for the economic slide during the past 30 years. $^{2}$

The results in this paper are from a recently published report ${ }^{3}$ which attempts to establish the distribution of qualification and experience areas for Key decision makers in New Zealand (only qualification results have been presented in this paper), highlight some studies which have been conducted overseas and raise other issues relating to qualifications and experience. It does not explore consequential questions such as factors leading to the distribution, nor the relationship between qualifications and company performance. 
Table 1. Accountants, engineers and lawyers per 10,000 working population. Selected countries

\begin{tabular}{lrlrll}
\hline Accountants & & Engineers & & Lawyers \\
\hline Australia 1991 & 112 & Sweden 1990 & 315 & USA 1990 & 63 \\
New Zealand 1991 & 97 & Japan 1990 & 228 & New Zealand 1991 & 39 \\
Canada 1990 & 71 & France 1991 & 184 & Australia 1991 & 35 \\
United Kingdom 1990 & 54 & West Germany 1989 & 180 & Canada 1990 & 33 \\
West Germany 1989 & 54 & USA 1988 & 153 & United Kingdom ‘0 & 32 \\
USA 1989 & 32 & United Kindom 1990 & 114 & Sweden 1985 & 24 \\
Sweden 1985 & 25 & Canada 1990 & 107 & West Germany 1990 & 21 \\
France 1991 & 10.7 & Australia 1990 & 106 & France 1991 & 2.3 \\
Japan 1990 & 1.9 & New Zealand 1991 & 50 & Japan 1990 & 1.6 \\
South Korea 1990 & 1.4 & & & South Korea 1990 & 1.3
\end{tabular}

Source: New Zealand - Membership of the New Zealand Society of Accountants, Institution of Professional Engineers of New Zealand, New Zealand Law Society. Other sources see Sagoo 1994

Accountants and lawyers versus engineers and scientists

Although it is commonly accepted that overall degree trends assist in determining the number of individuals available for employment, overall, it is difficult to use the distribution of degree types to explain the distribution of key decision makers with a qualification. There are many factors which can influence the number of graduates that will gain employment in their chosen fields and go on to become key decision makers.

According to Coates research on the number of accountants, engineers and lawyers per 10,000 people in the working population in New Zealand. ${ }^{4}$ Overall, New Zealand has the second highest number of accountants and lawyers for the ten countries data is available for and the lowest number of engineers. In New Zealand we have only 50 engineers per 10,000 workers while countries like Japan have 228 per 10,000 workers, see table 1 .

Coates suggests the low number of engineers is based on the low number of scientists and engineers on the board of directors of major New Zealand companies, which also contributes to a lack of incentives for young people to select science or engineering as a career. He also suggests that the application of the work for research scientists is largely the province of engineers and suggests perhaps there is not much scientific research for engineers to apply for which accounts for their lack of numbers. Coates results correlate well with those presented in Hooley and Franko's report. ${ }^{5}$ Hooley and Franko found New Zealand currently boasts around 11,000 qualified accountants in the workforce compared to a total number estimated for Japan and West Germany combined of only 9,800 (see table 2). Only in the UK does the high proportion of accountants in industry approach the levels of New Zealand.

According to the Bulletin of Agricultural Science on the need for more scientifically and technologically educated workforce, New Zealand has only 4,020 technologically qualified people in the workforce, this equates to 32 researchers $/ 10,000$ people in the workforce. ${ }^{6}$ Compare this to the OECD average of $47 / 10000$. Graduation statistics show that while there has been an increase in the total number of students graduating in all subjects, students in science and technology have decreased as a proportion of the total number of students obtaining first degrees. From 1978 to 1991 an extra 5,192 students graduated. However, only $12 \%$ graduated in science and technology while $53 \%$ graduated in law and commerce. Further, there were $22 \%$ fewer children studying sixth form science to the late

Table 2. Qualified accountants per head of population

\begin{tabular}{lll}
\hline Country & $\begin{array}{l}\text { Estimated Number of } \\
\text { Qualified Accountants }\end{array}$ & $\begin{array}{l}\text { Accountants Per 1000 } \\
\text { Population }\end{array}$ \\
\hline New Zealand & $\mathbf{1 1 , 0 0 0}$ & $\mathbf{3 . 3 3}$ \\
United Kingdom & $\mathbf{1 2 0 , 0 0 0}$ & 2.1 \\
USA & 300,000 & 1.25 \\
France & 20,000 & 0.36 \\
West Germany & 3,800 & 0.06 \\
Japan & $\mathbf{6 , 0 0 0}$ & $\mathbf{0 . 0 5}$ \\
\hline
\end{tabular}

Source: Hooley and Franko (1990, p10). Figures for NZ Accountants came from Handy, Gordon, Gow and Randlesome (1988). Exact definitions may vary from country to country. 
Table 3. New Zealand's key decision makers

\begin{tabular}{|c|c|}
\hline Sample Group & Individual Type \\
\hline Parliamentarians ${ }^{1}$ & All \\
\hline Public Sector ${ }^{2}$ & CEOs and Senior Executives \\
\hline Local Government & $\begin{array}{l}\text { CEOs, Senior Executives/Managers, Mayors and } \\
\text { Councillors }\end{array}$ \\
\hline Top 200 Companies $^{3}$ & $\begin{array}{l}\text { CEOs, Senior Executives/Managers, Chairpersons } \\
\text { and Directors }\end{array}$ \\
\hline Other 200 Companies & $\begin{array}{l}\text { CEOs, Senior Executives/Managers, Chairpersons } \\
\text { and Directors }\end{array}$ \\
\hline
\end{tabular}

1 Defined in 'Who's Who in the New Zealand Parliament', 1994.

2 Defined in Strata-MMR, 'A survey of New Zealand Public Service Senior Management, 1991.

3 As listed by Management Magazine, December 1992.

1980s than a decade earlier. ${ }^{7}$

To date, no study has been conducted to quantify the actual distribution of the qualifications and experience of New Zealand's key decision makers.

\section{Purpose of the paper}

This study sets out to achieve two elementary goals. The first is to give a brief overview of the claims made and related research undertaken in New Zealand and overseas with regards to the qualifications and experience of New Zealand's key decision makers.

The second is to present the results and a brief analysis of a survey conducted at the Ministry of Research, Science and Technology on the qualifications and experience of New Zealand's Key decision makers.

This paper does not examine whether there are too many or too few accountants, lawyers, scientists or engineers in key positions in New Zealand, it merely gives an account of the distribution of the qualification areas individuals in key positions in New Zealand have.

\section{Methodology}

The sample population had to represent people in key decision making positions throughoutNewZealand's public and private sectors. The data also had to be comparable with other international data. The study comprised of a literature review, a survey questionnaire and an analysis of previously published information where New Zealand's key decision makers are defined in the table 3.

Data for the key decision makers in local government were obtained from a questionnaire distributed to the 'Top 200' companies and the 'Other 200' companies. The 400 companies provide a reasonably complete coverage of key decision makers in the main commercial sector of New Zealand. For Parliamentarians and the Public Sector

\section{Table 4. Survey qualification and experience categories}

University Degree/Equivalent Polytechnic Qualification

Accounting, Business Administration, Economics, Law, Arts, Engineering, Science, Agricultural Science, Computer Science, Social Science, No Degree or equivalent and Other(s).

Other Post-Secondary Qualifications

Business Studies, Engineering, Science, Computer Science, No Post Secondary Qualification and Other(s).

Significant Occupational Experience 1

Accountancy, Own Company/Business, Human Resources, Marketing, Law Practice, Consulting, Teaching, Manufacturing, Farming, Engineering, Science and Technology, Information Technology, Medicine, PublicAdministration, Politics, Local Government and Other(s).

Note: Because derived information was used for the Public Sector, experience was only divided into previous private sector employment and state sector employment.

\footnotetext{
${ }^{1}$ Significant Occupational Experience is defined as an area where an individual has been employed professionally, or in a supervisory position or otherwise deployed a high level of knowledge or skills.
} 
information was readily available elsewhere.

The information gathered in the survey was divided into three general groupings: university degree/equivalent qualification, other post-secondary qualification and significant occupational experience. These are categorised as in the table 4.

\section{Results}

A total of 3,091 key decision making positions were selected. Of these 2,772 were surveyed. Qualification and experience information for New Zealand Parliamentarians and the Public Service Sector was derived from existing material. For the surveyed groups, an overall total response rate of $55 \%$ was obtained, this can be broken down as follows: top 200 companies $47 \%$, other 200 companies $46 \%$, local Government $71 \%$.

\section{Comparison of Findings}

The following results are only for the university qualifications of the key decision makers. Just over 55\% of all key decision makers have some form of university or equivalent qualification. Of those with university qualifications, accounting was by far the most popular followed by science and engineering. Figure 1 shows how for every key decision maker with a law qualification we have four who are qualified in accounting.

Figure 2 shows how accounting as a qualification dominates overall for the 400 companies surveyed. But it is also interesting to note there are more engineering and science graduates in the management teams of companies than on the boards. Also there are two times as many engineers in management than on the boards of the 400 companies.

Comparing the results for local government, there is a significant difference in the qualifications. Overall, key decision maker's in local government are a less likely group to have qualifications. This is especially true for the elected members of councils. Figure 3 shows that over $50 \%$ of Mayors and Councillors had no qualification. Of those with qualifications no subject area really dominates. However, in the management teams of local government, engineering was found to be more popular than accounting. The local government sector is the only sector to have more engineers in management than accountants.

Figure 4 compares the overall qualifications for the companies and local government. Although there are more engineering key decision makers in local government, there is still quite a similar number qualified in accounting in the 400 companies. Overall, there is a large difference between the number of accountants in the New Zealand companies compared with local government.

Figure 5 compares the management teams of the companies and local government. Here, the difference between the proportion of accountants and engineers is a lot more

\section{Figure 1. All key decision makers}

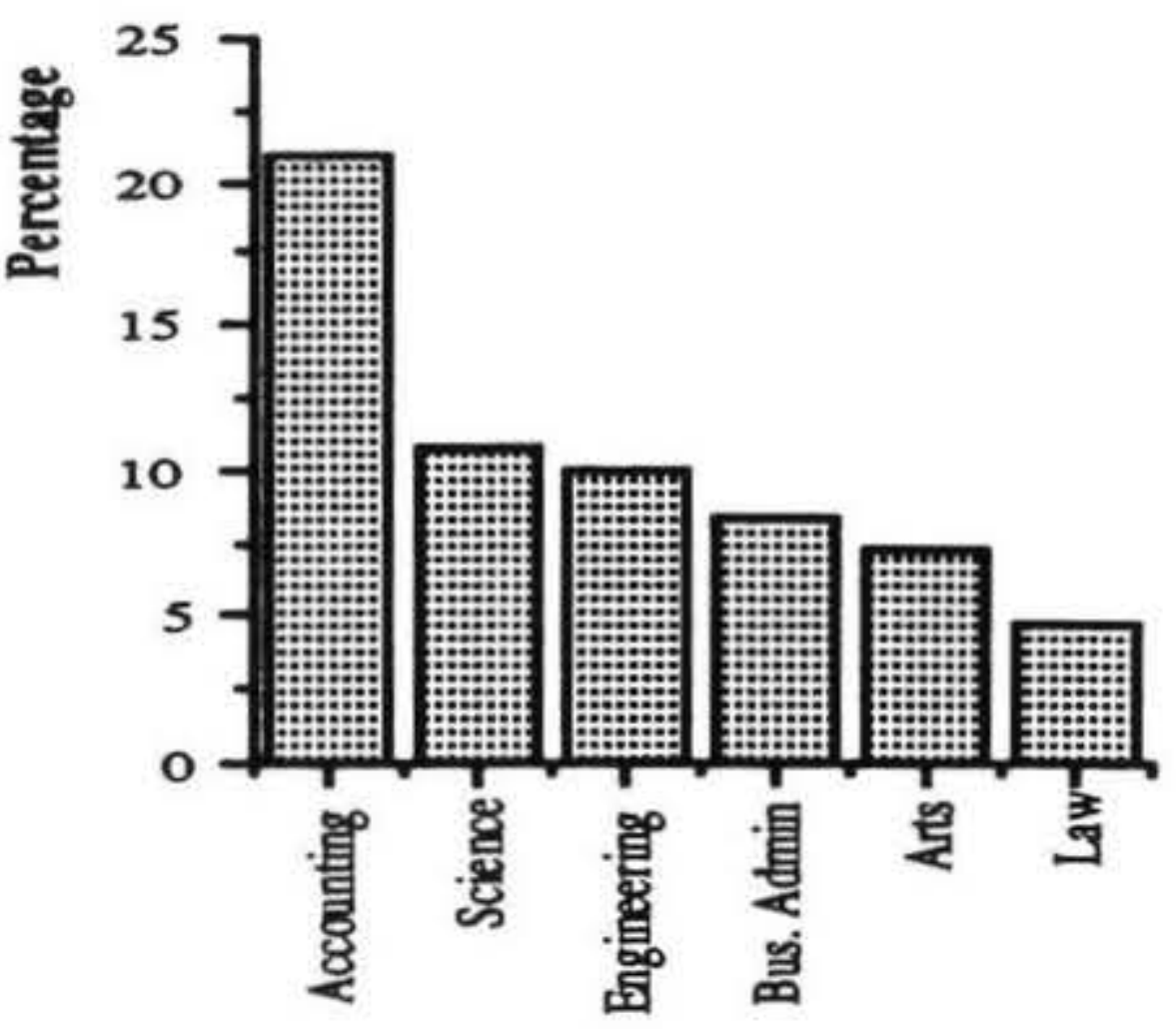

University qualifications

Figure 2. Qualifications in companies

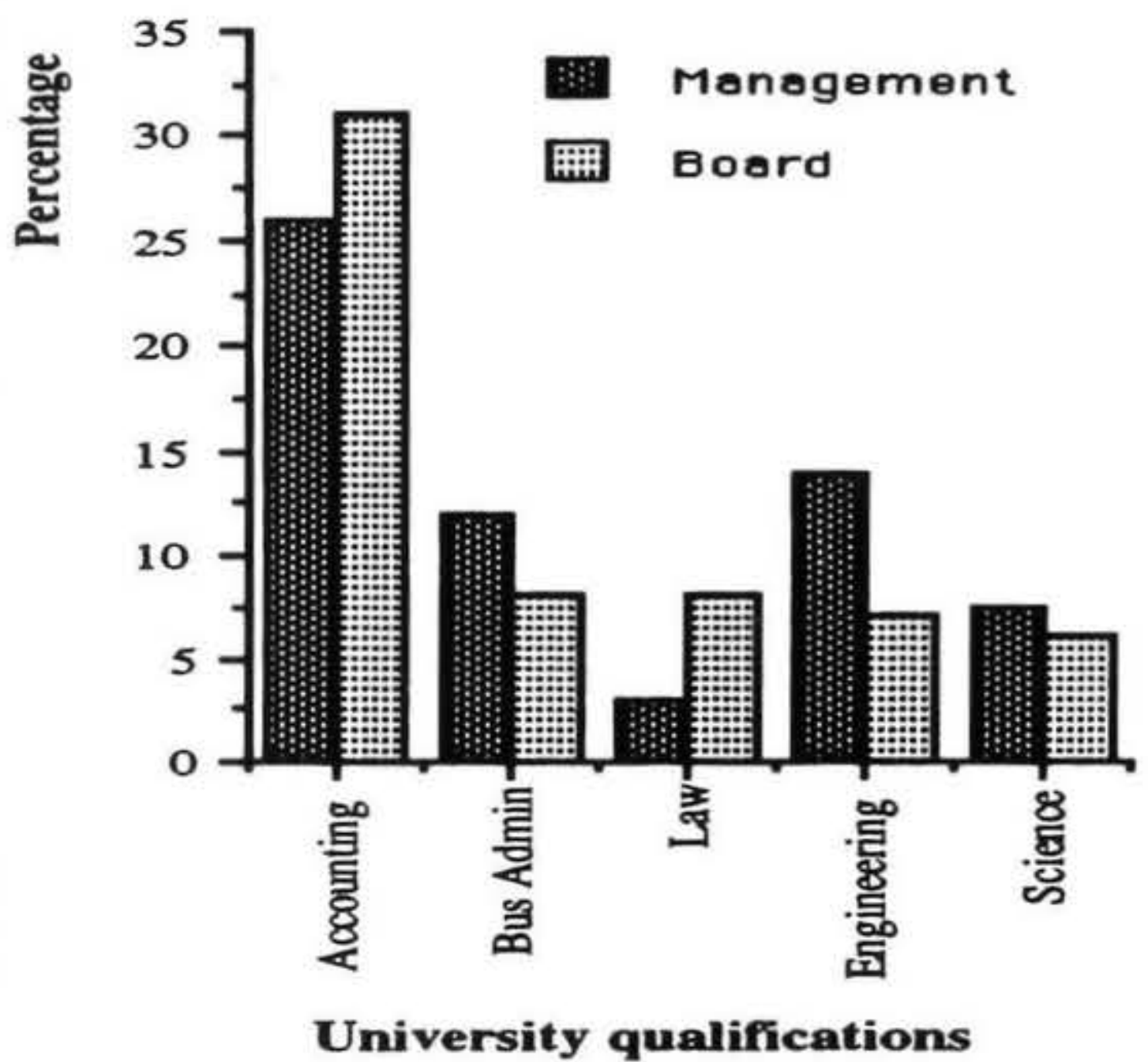

Figure 3. Qualifications in local government

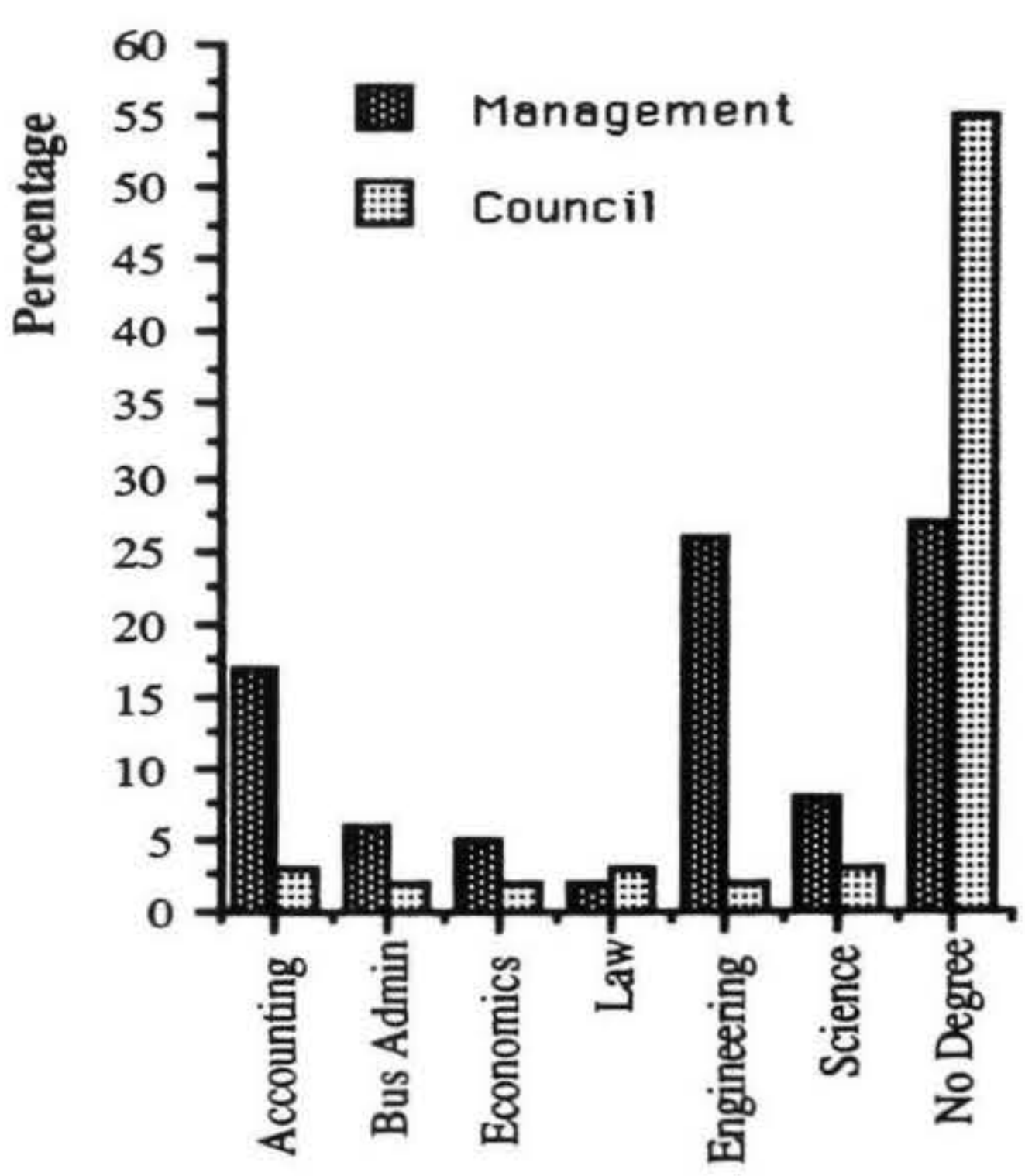

University Qualifications 
Figure 4. Qualifications - companies vs local government

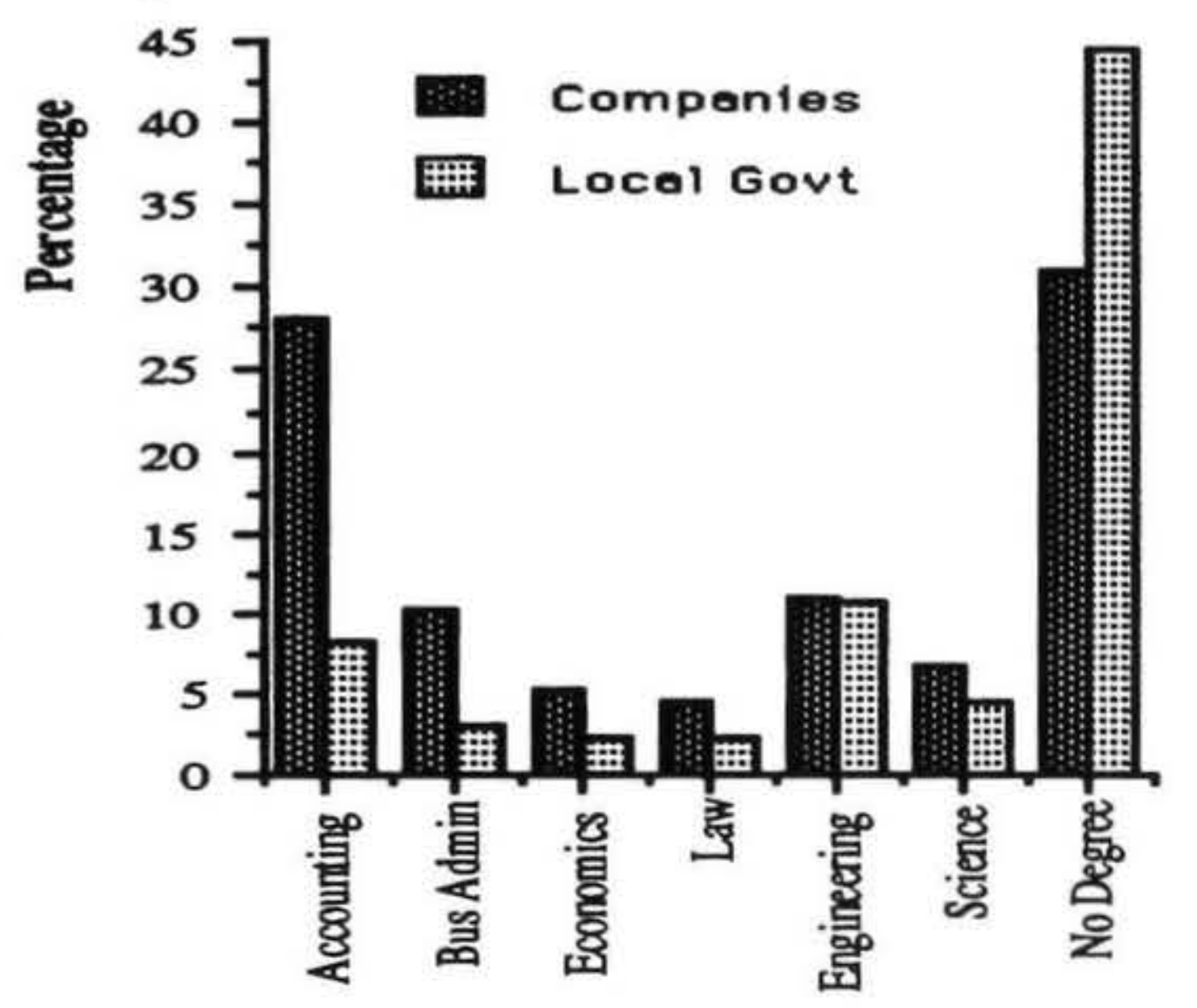

University qualifications

Figure 5. Management - companies vs local government

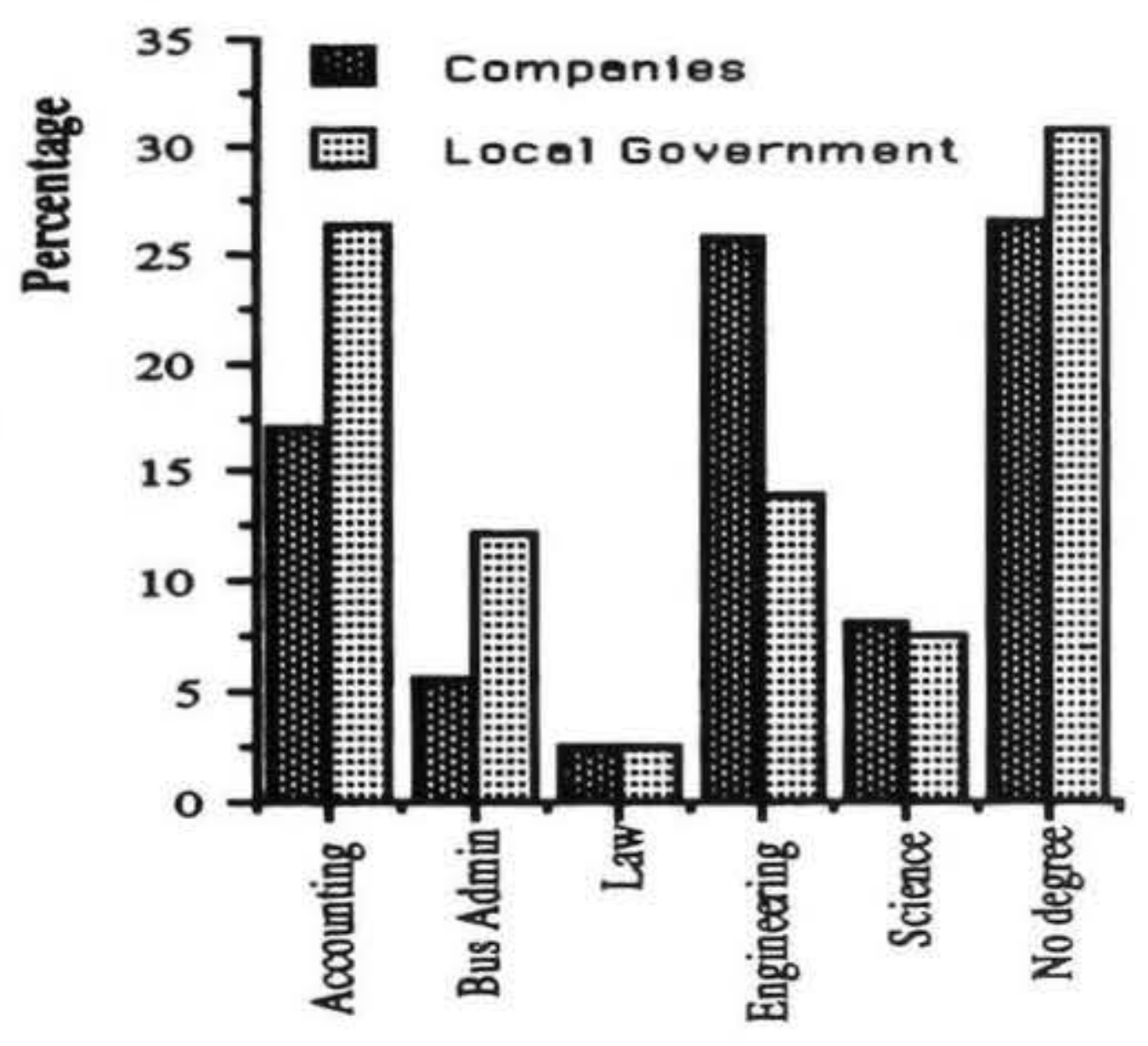

University qualifications

Figure 6. Qualifications - public sector vs companies

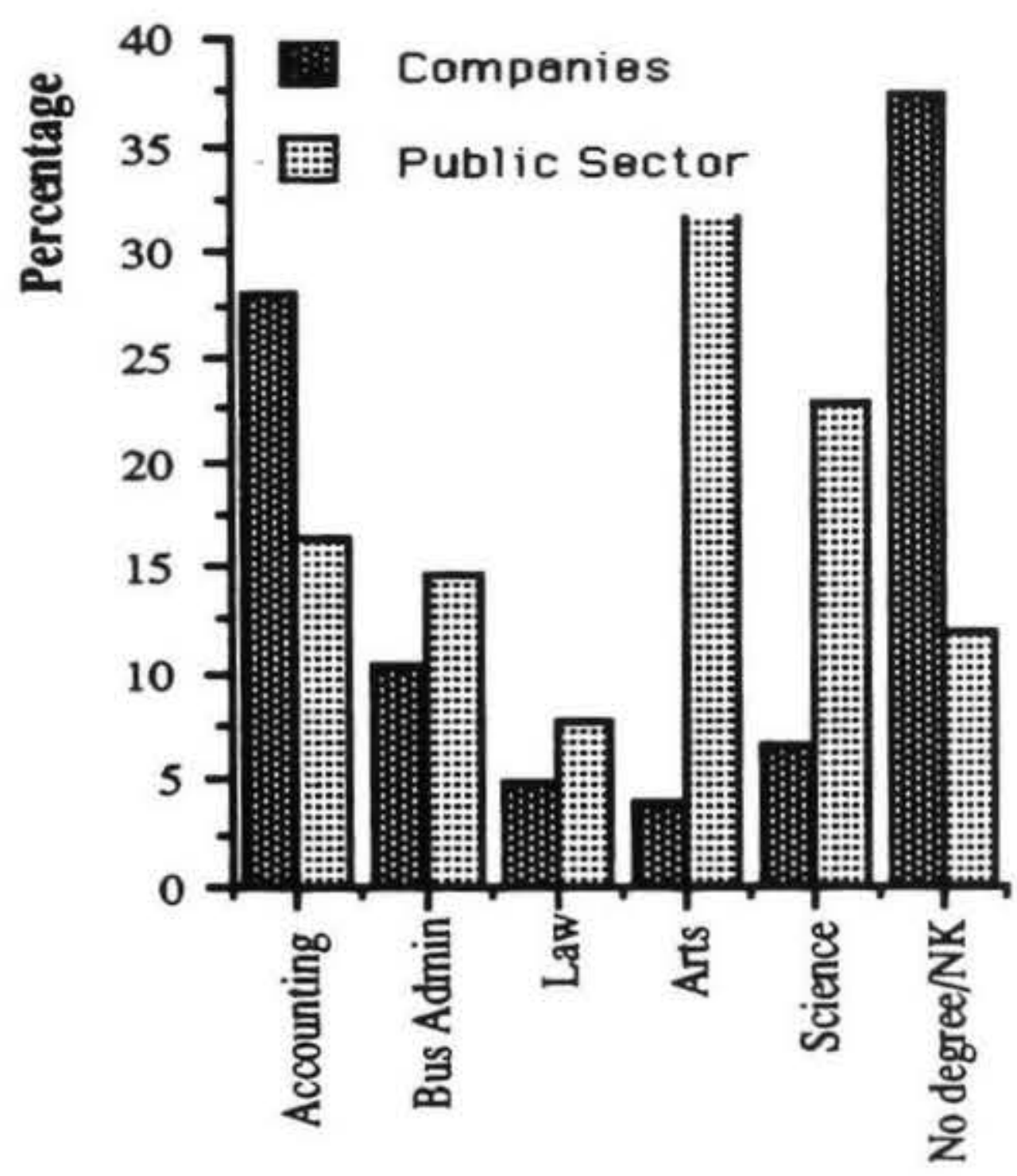

University qualifications apparent. Law has little showing in both areas.

Figure 6 compares information for the public and private sectors. Whereas in the private sector accounting dominates, in the public sector, key decision makers are more likely to have an arts qualification followed by science or technical university qualification(s). It is also interesting to note that more private sector key decision makers will not have a university or equivalent qualification.

Finally, figure 7 compares the university qualifications of New Zealand Parliamentarians and key decision makers in the public sector. Overall, of those Parliamentarians with qualifications, arts and law are the most common. While arts dominates in the public sector, science, accounting and business administration are also well represented.

\section{Other New Zealand research}

In New Zealand only one MBA study relating to the "Top 200' Companies Chairpersons and Directors was found. Some comparison with these and other New Zealand results were made. This survey was conducted by Dr Gordon Leary (1991) but only represented $34 \%$ of the 'Top 200 ' companies. Leary came up with the following recommendation: New Zealand companies should examine the composition of the boards and the processes used to appoint their Directors. There is room to improve the range, experience and qualifications on many boards. Manufacturing companies, primarily those involved in primary products, need more marketing and technological representation at board level. The Chairpersons identified these needs but, I believe they have been understated. Additional experience in marketing and technology can be brought to the board by replacing non-specialists or one of the two-three accountants normally present on a board (Leary, G., 1991, pxiii).

Overall, there was a high degree of correlation between the qualification and experience areas for Leary's results and those in this survey. In a later article Leary relates his results to the career paths of directors. He states that:

The dearth of scientist and engineers on boards, can be attributed to the relative shortage of scientists and engineers who have turned from a strictly technical career to have a direct involvement in the management of company affairs. Accountants on the other hand, more readily follow a career that leads directly into the management of a business: they probably also have traditionally spent more time mixing with company directors (Leary, 1992, Boardroom, Sept 1992, p5)

The report by Hooley and Franko also made data available to compare people in all general managerial positions in New Zealand. They found accountancy and related subjects were the single biggest occupational direction of recent graduates and the majority of students entering managerial positions came from courses in commerce. Of the managers listed by subject source there is one science graduate for every ten commerce graduates (see table 5). 


\section{Figure 7. Qualifications - parliamentarians vs public sector}

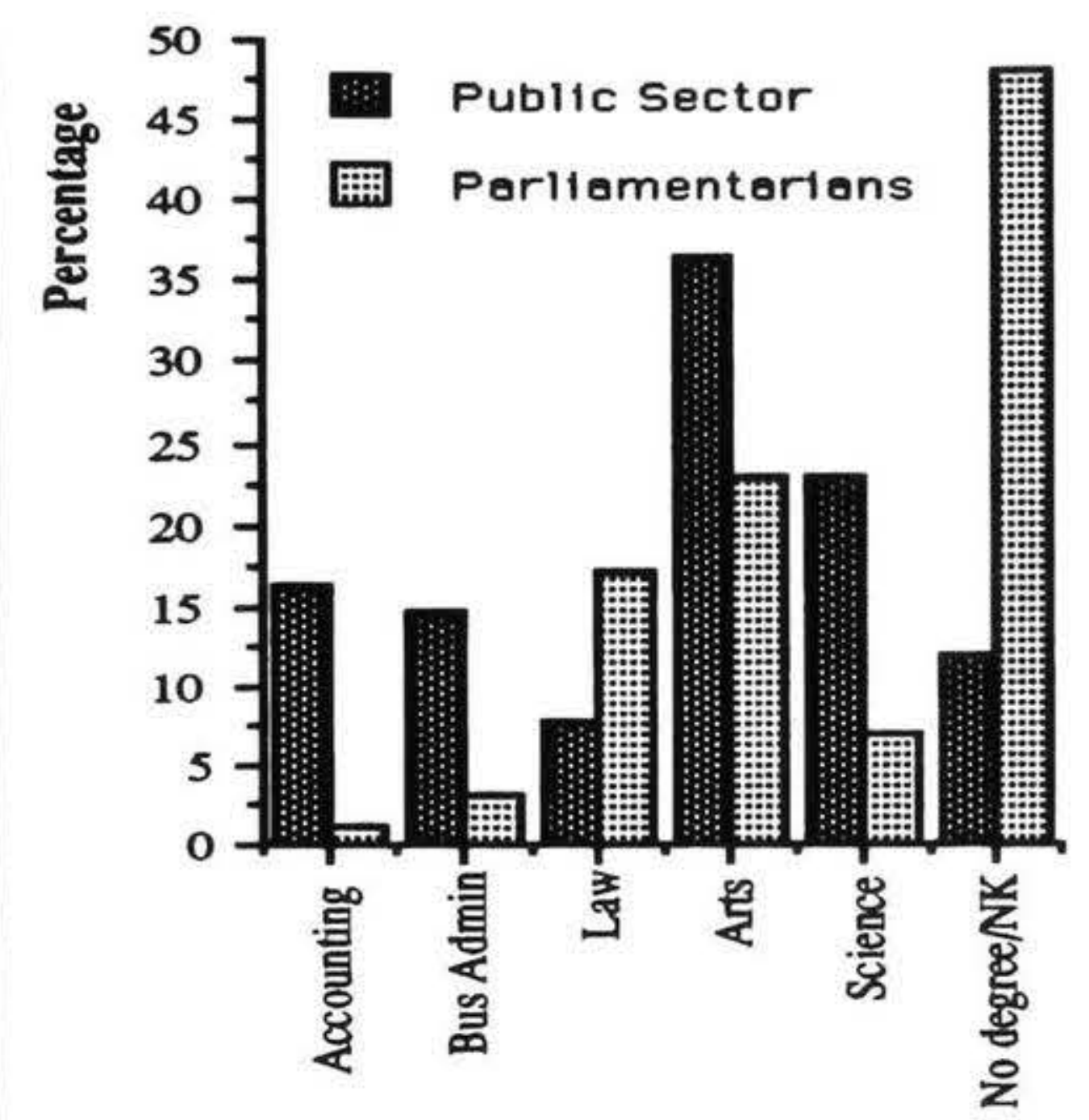

University qualifications

Figure 8. Chief Executive Officers - New Zealand vs United States

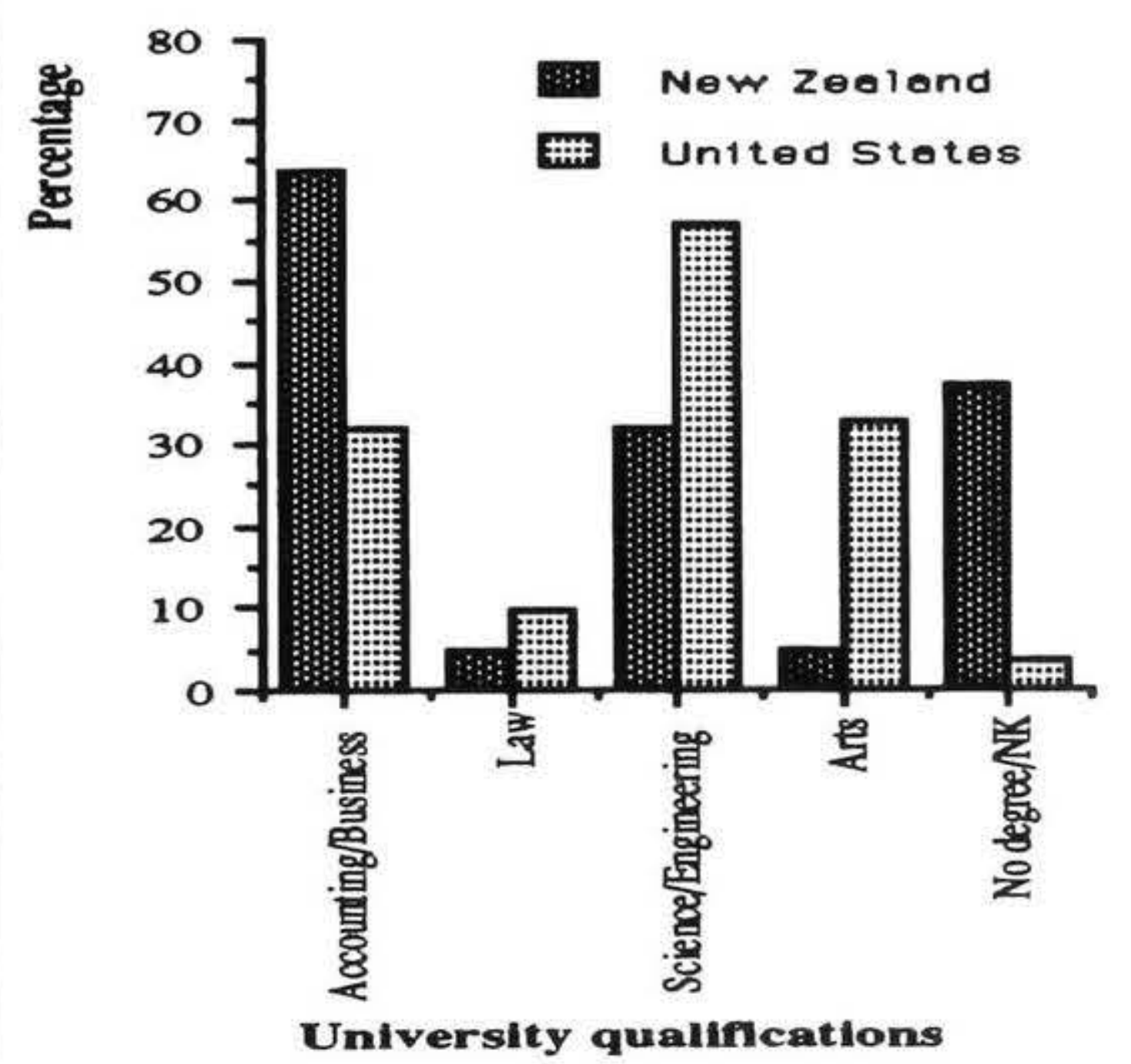

Table 4. Graduates entering into industrial and general management trainee positions

Subject Areas

Commerce

Number of Graduates

Arts

Science

21

Agriculture and Forestry

Another recently released report by Page and Wilson analyses the existing managerial competencies as perceived by 1,650 New Zealand managers, academics and MBA students the results explain a particular style and quality of management in New Zealand. ${ }^{8}$ The report found that, technology and innovation were not recognised as important elements of managerial competencies in New Zealand business enterprises, however, the authors were concerned this pattern did not augur well for New Zealand companies needing to be competitive in a global trading environment.

\section{Overseas findings}

When comparing the New Zealand data with overseas information it is important to note, the number of degrees differed from country to country due to differences in cultural and educational systems. Social factors such as the industrial structure and number of students can also affect the number of graduates. Therefore, it is difficult to compare the data at face value and only limited international data was used.

In the United States of America an analysis of the qualifications of 'The Corporate Elite', reflects the high number of managers with MBAs found in the USA. ${ }^{9}$ Information on the College Education, Graduate Study and Career Path for each Chief Executive Officer (CEO) was available and this was compared to the results for Chief Executive Officers of the 'Top 200' New Zealand companies.

Figure 8 shows how New Zealand CEOs are more likely to have an accounting/ business qualification than CEOs in America. New Zealand CEOs are also less qualified in law and more qualified in science/engineering. This difference could be attributed to the large number of New Zealand CEOs with no qualifications. Further, in the USA having more than one degree in different qualification areas is more common. Forty percent of American CEOs were found to have engineering degrees and twenty five percent went on to do MBAs.

Research conducted by Scherer and Huhanalysing data spanning 17 years on R\&D expenditure and the University educational background of top managers for 221 relatively research-intensive US corporations, found an educational background in science or engineering for top executives, perhaps complimented by legal and business skills appeared more conducive to intensive R\&D spending. 10 This also relates to research on the shift in the functional backgrounds of newly appointed presidents of the largest 100 US corporations by Haynes and Abernathy. 11 Work by Roberts and Sarnoff also found that one of the keys to linking science and technology to the overall corporate strategy was (in $60 \%$ of cases) that, the Chief Executives involvement was considered very important. 12 Other research conducted by Heilmeier found, amongst the most successful companies in Japan, Europe and the United States, the proportion of technically trained Chief Executive Officers is higher than those in the US businesses overall. ${ }^{13}$

Japan focused tremendous resources on education to provide the highly educated and trained work-force required for economic growth and success. According to Gow, 
Japan's amazing postwar recovery, her emergence as an economic super power and her efforts to achieve major status as a leading technological and scientific nation all occurred after the war. ${ }^{14}$ Japan placed emphasis on being a value-added, export-oriented economy and concentrated on licensing technologies rather than financing major basic research and development programs.

Heilmeier research also found the Japanese Ministry of Internal Trade and Industry (MITI) had in 1990 surveyed nearly $\mathbf{5 0 0}$ companies and found $39 \%$ of company presidents had experience with technology and/or production backgrounds; $36 \%$ of company president had experience with technology and/or production; and $90 \%$ of Japanese Chief Technology Officers hold positions on boards of directors or equivalent in managing boards. This was compared to European and US firms. In short, in spite of their heavy dependence on technology US companies were found to be reluctant to give technology a seat on the inner circle in the US whereas in Japan and Europe stronger links exist between technology strategy and overall corporate strategies.

In the United Kingdom an article by Kenward called for companies to drag scientists to the boardroom, he makes this claim, however, he also stated that:

'I can find no useful academic study of the country's top 100 , let alone 500 companies detailing the constitution of their boards.' 15

However, recent research conducted on a sample of engineering related companies by Bosworth found companies run by people with scientific or technological qualifications do better than those run by accountants and financiers. 16 His findings were based on the concern over the quality of British management and the lack of graduates and individuals with professional science and engineering qualifications in senior managerial roles.

In Australia, similar trends overall were found for the qualifications of key decision makers on the boards of the most populous companies in relation to the qualifications found for people in the community with comparable qualifications. The study was conducted by Stephen Coates who found accountants stand out easily as the most popular on the boards. 17 Law came in second followed closely by commerce/economics/business administration. The most poorly represented qualification areas were holders of science degrees (28 out of 10,900$)$ and engineers were only slightly under-represented (47 out of 6,300). Of the 411 directors, there are only four in the scientific or technological area. From his findings he concludes that'People with science degrees are not unwanted, it is just that accountants and lawyers are wanted more'.

\section{Overall findings}

From the interpretations to date, generally it was found that for the qualifications and experience of New Zealand's key decision makers, different qualification areas dominated in the different sectors. Similar trends were observed for significant occupational experience (see table 6).

\section{Table 5. Qualifications of key decision makers}

Key Decision Maker

DominantQualification Area

\begin{tabular}{ll}
\hline Parliamentarians & Arts and Law \\
Public Sector & Arts, then Science/Tech \\
Local Government & Engineering, then Accounting \\
Top 200 Companies & Accounting, then Engineering \\
Other 200 Companies & Accounting, then Engineering \\
\hline
\end{tabular}

Overall

Accounting, thenEngineering

However, it is important to note these key decision makers probably obtained their qualifications $20-30$ years ago and the date, country of origin for qualifications or experience was not surveyed. Further the types of options for study and career advancement have changed over this period.

The results also showed that the number of key decision makers with computer science qualifications is very low. This is not surprising since computer science and information technology qualifications and experience have only recently become available and recognised. Key decision makers will find they have to rely more and more on technology as a tool to facilitate their survival and competitive advantage. In the future, it is likely that computer science and technical qualifications will be represented more in key decision making positions. So, if this survey is used as a benchmark, it will be interesting to see which qualification and experience areas dominate 5 or 10 years in the future.

Therefore, overall for New Zealand's key decision maker's qualifications, accounting dominates followed by engineering. And from the New Zealand findings to date we can state that over $40 \%$ of New Zealand's key decision makers do not have a post-secondary qualification. Of those with qualifications most are connected with business through business backgrounds and accounting (rather than law) is the most likely qualification. There are relatively few scientists in key decision making positions (and this appears to be of concern for individuals in science and technology related fields). Finally, the international data suggests there is a direct link with the backgrounds of key decision makers and their competency in decision making with respect to issues such as technology and gaining competitive advantages through technological innovation.

\section{Conclusion}

If it is accepted that after finance, marketing and technical development are the most important factors contributing to international competitive advantage then, in the future 
New Zealand's key decision makers do not appear to be well qualified. However, more research and analysis is required in order to draw more general conclusions.

Such information has not been compiled in New Zealand before (and for such a large sample population). As such it can serve as a benchmark for other and future surveys and serve as a factual basis for discussion.

\section{Future research}

Though no specific results have been derived from the research to date, further questions and opportunities for research arise. Examples include:

* Is it because of the mix of business sectors in the economy that we have the mix of qualifications and experience represented here?

* Have opportunities for promotion or movement only been open to key decision makers with the qualifications and experience represented here?

* What effect does this mix of qualifications and experience have on competitive business activity?

* Is there a relationship between company profits and turnover with the qualification and experience of the key decision makers?

* What other factors dominate in assisting an individual to become one of the key decision makers defined in these results?

\section{References}

Anon, 1993 Science in New Zealand, in Bulletin of Agricultural Science, May.

Anon, 1992 Who's on the board?, in Boardroom, September:5.

Bosworth, D., Wilson, R. and Taylor, P., 1992 Technological Change:the Role of Scientists and Engineers, Avebury, Ashgate Publishing Limited, England.

Coates, S., 1990 Science needs a seat on the company board, in New Scientist, 128, 1744:4.

Coates, S., 1991 A nation of bean counters. New Zealand Business, November: 18-19.

Corben, R., 1993 'Key reasons for economic slide of NZ over the Years', Evening Star, quoting Porter, ME., 10 September 1993.

Crocombe, G.T., Wright, M.J. and Porter, M.E., 1991 Upgrading New Zealand's Competitive Advantage, Oxford University Press.
Handy, C., Gordon, C., Gow, I. and Randlesome, C., 1988 Making Managers, Pitman Publishing, London.

Haynes, R., and Abernathy, W., 1980 The American Managerial Ideal, part of 'Managing our way to economic decline' in Harvard Business Review, 58, 4:67-77.

Heilmeier, G., 1993 Room for Whom at the Top? Promoting Technical Literacy in the Executive Suit, in Research, Technology management. The IRIMedallist's Address, 36, 6:27-32.

Hooley , G.J., and Franko, G.D., 1990 The Making of New Zealand Managers:Management Education, Training and Development for the 21st Century, University of Otago Business School, September.

Kenward, M., 1991 Take science on Board, in New Scientist, 130, 1773: 52-53.

Leary, G., 1991: 'New Zealand company boards - their role and composition and how they keep up with technology', A summary of a research report as part requirement for an MBA, September 1991.

Page, C., and Wilson, M., 1993: 'Managerial competencies and New Zealand Managers', University of Auckland.

Pearson, M., 1993 New Zealand's Top 50 Local Bodies', Management Magazine, 40,4:33-51.

Sagoo, B., 1994, The qualifications experience of New Zealand's key decision makers, Ministry of Research, Science and Technology, Report no. 27, Wellington.

Scherer, F.M. and Huh. K, 1991 Top managers Education and R\&D investment', in Research Policy, North Holland 21:507-511.

West, A., 1993: 'The challenge to New Zealand Science and Technology', unpublished essay April 1993.

\section{Notes}

${ }^{1}$ Crocombe, et al, 1991, p 106.

2 Porter, 10 September 1993, reported by Corben, $R$ in the Evening Star, 'Key Reasons for Economic Slide of NZ over the Years'.

${ }^{3}$ Sagoo, B., 1994: 'The Qualifications and Experience of New Zealand's Key decision makers', Ministry of Research, Science and Technology, Report No. 27.

4 Coates, S., 1991, 'A nation of bean counters' in New Zealand Business, November 1991, p18-19.

5 Hooley, G.J and Franko, G.D., 1990: 'The Making of New Zealand Managers: Management Education, Training and Development for the 21st Century', University of 
Otago Business School, September 1990.

${ }^{6}$ Bulletin of Agricultural Science, May 8, 1993. Information derived from West, A (1992) and Hooley and Franko (1990).

7 Information derived from West, A., 1992 and Hooley and Franko, 1990.

8 Page, C and Wilson, M. 1993: 'Managerial competencies and New Zealand Managers, University of Auckland. ${ }^{9}$ The Chief Executives of the Business Week 1000, most valuable publicly held U.S. Companies.

${ }^{10}$ Scherer and Huh, 1991, 'Top managers education and R\&D investment', Elsevier Publishers B.V., p 507-511.

11 Haynes, R., and Abernathy, W., 1980, 'The American Managerial Ideal', reported in Managing our way to economic decline in Harvard Business Review, July-August, 1980, p67-77.

12 Edwards B Roberts (Chairman, Pugh-Roberts Associates, a division of PA consulting group) \& David Sarnoff (Professor of Management of Technology, MTT Sloan School of Management).

13 Heilmeier, G., 1993, 'Room for Whom at the Top? Promoting Technical Literacy in the Executive Suite', in Research, Technology Management, The IRI Medallist's Address, November-December 1993, p27-32.

${ }^{14}$ In Handy, Gordon, Gow and Randlesome, 1988, 'Making Managers'.

15 Kenward, M., 1991, 'Take science on Board', in New Scientist, 18 June 1991, p 52-53.

${ }^{16}$ Bosworth, D., Wilson, R and Taylor, P, 1992, 'Technological Change: the Role of Scientists and Engineers', Avebury, Ashgate Publishing Ltd, England, pp 137.

17 Reported in New Scientists, 24 November 1990, p4.

\section{Author}

At the time this paper was written, Baljinder Sagoo was a Policy Researcher at the Ministry of Research Science and Technology. Baljinder is now an independent consultant. 